\title{
Peoples' Participation in the Physical Planning Activities: A Case Study of Khulna Development Authority
}

\author{
Sabrina Ahmed" \\ Mohammad Shahidul Hasan Swapan ${ }^{* *}$
}

\begin{abstract}
In contemporary world, community participation is considered as the prerequisite of sustainable urban development. It ranges from just informing people about the plan or development projects by the people. However, public participation in local government's led programs is still limited in Bangladesh. Considering the importance of community participation, this paper explores the level of public participation in spatial planning practices in Khulna city based on the citizen's responses. The study suggests that existing legislative arrangement is not supportive for participatory urban development at all levels and a little provision is made in this respect by laws. Most of the respondents in the field survey suggested that political problem and weak communication mechanism are mainly responsible for unsuccessful implementation of the Master Plan of Khulna city. The study may help related authorities to understand the citizen's expectations in designing strategies for performing better role in city development in Bangladesh.
\end{abstract}

\section{Introduction}

The concept of participation has been subject to lengthy debates regarding its historical origin, theoretical grounding and practical applicability (Mikkelsen, 2005). It ranges from just informing people about the plan to making of plan or development projects by the people. The level of public participation may vary over time, place and activities. In global arena, the tokenistic participation concept has replaced the blue print planning and finally the theory of pluralism has been introduced (Lane, 2005). Public participation strategies in the planning process has been recorded and added to the growing volume of literature of planning and come up with a new vision of planning process in response to the sustainable outcome of planning and development initiatives. In the late 1960s, when interest on peoples' involvement was skyrocketing, Arnstein (1969) developed a model to show that there are many degrees or levels (from informing to peoples' delegation) to which public can be involved in development projects. Table 1 shows the suggestions made by Arnstein (1969) and Mitchell (1997) on types and nature of people's participation.

Participation is one of the most important concepts in planning and development, because it is potentially a vehicle for different stakeholders to influence development strategies and interventions, which are mostly dominated by professional experts in the government and private sector. Participation combines the experiences, knowledge and understanding of various groups and citizen (Mitchell, 1997).

Participatory planning methods in a wide range of forms are being spontaneously incorporated around the world in response to the failures of other methods used for city development. These are sometimes instigated by government and sometimes outside government, but either way they tend to involve governmental and nongovernmental entities as well as citizens in long term dialogue, mutual learning processes, and joint action (Innes and Booher, 2000). This new paradigm of planning demands a shift from the traditional legal structure and establishment of democratic

\footnotetext{
* Urban Planner, 43/1 East Link Road, Khulna, Bangladesh

** Assistant Professor, Urban and Rural Planning Discipline, Khulna University, Khulna, Bangladesh, Email: eswapan@yahoo.com
} 
rights of the citizen. However, public participation in the functions of local government is still limited in Bangladesh. In fact, local governments are slow in initiating effective program or in devising innovative actions (Islam et al., 2001). Most of the city's Master Plans lack in public involvement and have not been successful in the long run, which has been blamed for not incorporating peoples' ideas and needs. Still there is a wide scope for public participation in city planning and development activities carried out by the local authorities to ensure sustainable city development (Enyedi, 2004).

Table1: Degree of citizens' participation

\begin{tabular}{|c|c|}
\hline Types of Participation & Nature of Participation \\
\hline Passive Participation & $\begin{array}{l}\text { People participate by being told what is going to happen or has } \\
\text { already happened, with no ability to change it. The information } \\
\text { being shared belongs only to external professionals. }\end{array}$ \\
\hline $\begin{array}{l}\text { Participation in } \\
\text { information giving }\end{array}$ & $\begin{array}{l}\text { People participate by answering questions posted by the } \\
\text { authorities/agencies. People do not have the opportunity to } \\
\text { influence proceedings, as the findings are neither shared nor } \\
\text { checked with them. }\end{array}$ \\
\hline $\begin{array}{l}\text { Participation by } \\
\text { consultation }\end{array}$ & $\begin{array}{l}\text { People participate by being consulted, and implementing } \\
\text { authorities listen to views. The authorities define both problems } \\
\text { and solutions and may modify these in the light of peoples' } \\
\text { response. The consultative process does not share in decision- } \\
\text { making and the authorities are under no obligation to take } \\
\text { people's views on board. }\end{array}$ \\
\hline $\begin{array}{l}\text { Participation for material } \\
\text { incentives }\end{array}$ & $\begin{array}{l}\text { People participate by providing resources such as labor and land } \\
\text { in return of cash or services or any material incentives. People } \\
\text { have no stake in prolonging activities when the incentives end. }\end{array}$ \\
\hline Functional participation & $\begin{array}{l}\text { People participate by forming groups or committees, which are } \\
\text { externally initiated. Groups/committees are seen as means to } \\
\text { achieve predetermined goals. }\end{array}$ \\
\hline Interactive participation & $\begin{array}{l}\text { People participate by being involved in planning and } \\
\text { implementation phases. Communities take control over local } \\
\text { decisions and people have to stake in maintaining structures or } \\
\text { practices. }\end{array}$ \\
\hline Self-mobilization & $\begin{array}{l}\text { People participate by taking initiatives to change systems } \\
\text { independent of external institutions, although the later can help } \\
\text { with enabling framework. }\end{array}$ \\
\hline
\end{tabular}

Source: Prepared by authors from Arnstein, 1969; Mitchell, 1997.

Considering the importance of community participation for sustainable urban development, success history in international cases and the potentials in Bangladesh, this paper aims to explore the public participation in spatial planning practices in Khulna city. The investigation also covers organizational arrangement, planning activities and development control (e.g., enforcement of planning laws, preparing Master Plan, service delivery and improvement / re-housing projects, etc.). 


\section{Role of Peoples' Participation in Urban Planning}

A number of purposes are there for public participation in planning and decision-making. One is simply for decision makers to acquire information about the peoples' preferences, so that they can play a part in the decisions regarding projects, policies or plans. Public participation helps transform peoples' will into reality. A second and closely related purpose is to improve the decisions made by incorporating the knowledge of the public or members of the public into the calculus of the decision. Thus, people in a local community may know about the traffic or crime problems on a particular street, and the planners and decision makers can learn about these issues through public involvement. Enyedi (2004) argued that politicians, decision makers and administrators are not self sufficient to produce a sustainable urban development plan. Again, the representative democracy is not enough for a comprehensive and equitable development, as the elected politicians do not represent a particular social professional group. Planners, on the other hand, have limited knowledge about the actual local problems. Moreover, statistical data or projection tools do not always imply the citizens' feelings or expected solutions. According to Enyedi (2004), the key objective of public participation is to help decision making in a more realistic way and to avoid several conflicts, protest, movements and actions.

During the United Nations Conference on the Environment and Development (UNCED) in Rio de Janeiro in 1992, it was suggested that municipalities produce their own sustainable development programs, called Local Agenda 21. The Local Agenda 21 has already catalyzed wide public participation in Finish cities (Lehtonen, nd). Lehtonen (nd) also described the increasing public participation in cities of Baltic Sea regions especially in landuse planning, new housing development and involvement of NGOs in planning activities. Again, urban renewal and housing projects in European cities offer several examples of public participation. One of these is the AURA (Aszbdi ut rehabilitation Action) carried out in Budapest, Hungary, from 1993 (Enyedi, 2004). Hundreds of examples of collaborative planning can be found at all scales from local to national around the world. In Europe, many municipalities have voluntarily begun collaborative processes to implement Local Agenda 21's mandate (Maier, 2001).

\section{Study Framework}

In this study, peoples' participation is studied under two major areas: policy level and community level. At policy level, this research investigated the legal arrangements (ordinance and laws), opportunities and prescription of participation in Master Plan and project preparation (e.g., rehousing/urban re-generation) and implementation. This study also defines the participation as the peoples' access to the information (regarding the activities/projects/services of KDA) as well as citizens' response and practice in implementing planning control mechanisms (setback rules and building construction). Community practices specifically encompass their knowledge and practice of building construction rules and involvement and awareness about Master Plan preparation in their city. To identify the scope of peoples' participation in policy documents, different Acts and Ordinances related to city planning were critically reviewed. A semi-structured questionnaire survey was also conducted to get the opinion of the related officials and experts. Community practice in applying planning laws and satisfaction over the activities of KDA were carried out through observation and questionnaire survey using stratified sampling technique in planned (48 households) and unplanned (102 households) residential areas of Khulna city. The findings of the field surveys are dicussed here.

\section{Findings and Discussions}

\section{Scope of Peoples' Participation Stated in Policy Documents}

Legal environment plays a crucial role in order to ensure involvement of citizen in the planning activities. Traditionally, the Terms of Reference (ToR) between planning authorities and consulting firms for preparing master plan act as legal instrument to guide towards integrating 
citizen in the planning process. Town Improvement Act (TIA), 1953 was the first legal instrument in Bangladesh prepared for city planning and development. This Act does not suggest for involving people during plan preparation and need assessment. Other legal documents especially the ordinances of different city development authorities in Bangladesh were prepared following the TIA directly. The general procedure for master plan preparation prescribed by those legal documents show that people will be notified (through mass media/ official messengers/notice board of the authority) for receiving objection about the draft master plan and the objections will be accepted within the sanctioned time. It also suggests that there is no direct regulatory support for participatory demand assessment during plan preparation rather only limited participation is prescribed as by-laws [Town Improvement Act 1953: section 73(4); Khulna Development Authority Ordinance 1961: section 22(3) and (4)]. Similar opportunities are observed in case of improvement/re-housing scheme and urban regeneration projects.

Again, the ToR prepared for the Master Plan of Dhaka, Chittagong, Khulna and Rajshahi cities clearly prescribed to carry out consultation with the communities for need assessment. In the Master Plan, three phases of consultation were suggested, which are: 1) Communication Plan (First Consultation); 2) Formulation of Planning Principles/Standards (Second Consultation) and 3) Community based Development Approach (Third Consultation). It is interesting to observe that documents, like Dhaka Metropolitan Development Plan, 2000; Chittagong Metropolitan Master Plan; Detailed Area Plan (DAP) of Dhaka, 2004-2007 do not define clearly on how community views have to be addressed in preparing the plan.

\section{Scope of Participation in the Activities of KDA}

KDA was created as a semi-autonomous body in 1961 under the 'Khulna Development Authority Ordinance, 1961. It was established for planned development and expansion of Khulna city and its suburb areas. There is no prescribed option for peoples' participation (zero level participation) in the KDA Ordinance for the development of Khulna city. As a result, people's participation is now completely a non-binding activity for KDA. There is no guidance to integrate people or identify their needs in development initiatives (e.g., Master plan preparation, infrastructure development, improvement and re-housing scheme) taken by KDA. It could, at least make some provisions to circulate the information regarding development control and new projects among the citizen of Khulna city. Moreover, the job description of KDA officials and working sections (especially Chairman, Chief Engineer, Authorized and Planning sections) does not consider any sort of participatory mechanism to carry out their tasks, which are very much community oriented. Only two Ward Commissioners (people's representatives) of the Khulna City Corporation are included in the Executive Body of KDA. Furthermore, KDA has fourteen sectoral policies for the development of the city, among which only housing sector policies set out for promoting participatory development process. Figure 1 describes the level of participation available in the policy area as well as the current practice of KDA according to the ladder of citizen participation developed by Arnstein (1969). The figure was compiled through reviewing the policy and project documents of KDA and interviewing the key informants.

The trend of practicing lower level of peoples' participation can also be observed in other development authorities in Bangladesh (e.g., Dhaka, Rajshahi and Chittagong). It is found that this option is not mandatory for the development authority, but it is found in TOR documents. According to ToR, consultants are agreed to assess and integrate the demand and aspiration of the communities in program/project design and implementation phases. The TOR of DAP in Dhaka Metropolitan Development Planning (DMDP), 2000 included a very tokenistic peoples' participation. In step-8 (working procedure) of the TOR in DAP, it was encouraged to consult with the local communities to understand and prioritize their problems. DAP suggested to conduct community meeting with the interested community groups only. This was a positive indication of introducing peoples' involvement in city development, but the consultants were not legally bound rather they were just only encouraged. 


\section{Planning Knowledge of Citizens in Khulna City}

The planning knowledge of the citizen represents that how successfully KDA provides the planning information to them as well as the citizens' attitude in practicing planning rules and regulations. KDA uses information booklet, website, citizen charter, wall writing and miking for information dissemination. KDA also started One Stop Service Center and website in 2008 to minimize the hassles during the interaction with the people. As internet connection is not available in most of the houses in the city, it contributes a little to inform the people about KDA services.

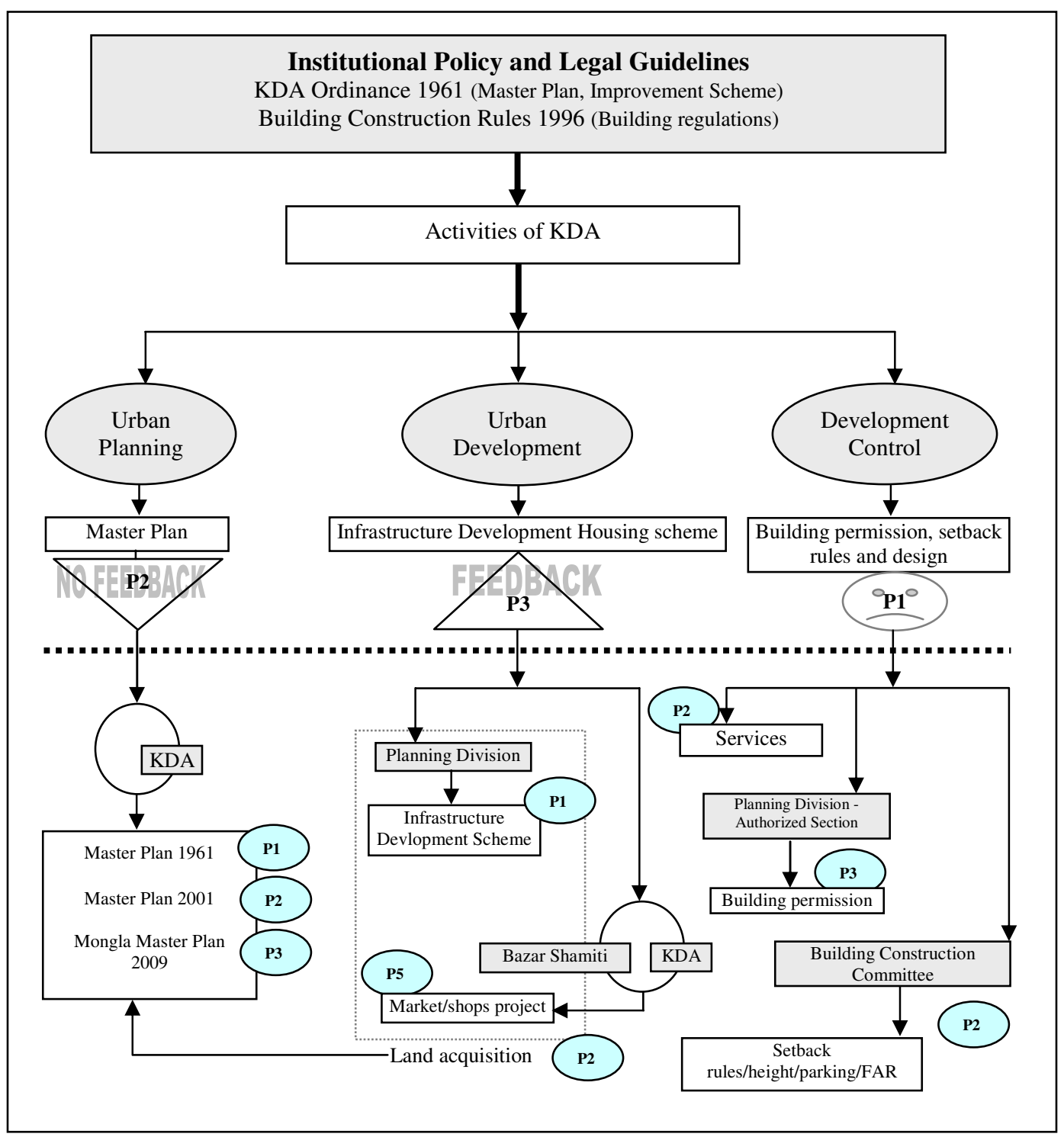

Note: $\mathrm{P} 1$ = No Participation, $\mathrm{P} 2$ = Information Giving, P3 = Participation by Consultation, $\mathrm{P} 4=$ Participation for material incentives, $\mathrm{P} 5=$ Functional participation, $\mathrm{P} 6=$ Interactive participation and $\mathrm{P} 7=$ Self-mobilization

Fig. 1: Options and level of peoples' participation in the policy documents and current activities of KDA 
Despite having a number of dissemination tools, the level of knowledge of the citizens was found moderately satisfactory. Seventy five percent of the surveyed household owners had clear idea on building permission procedure of KDA. Only half of the total respondents knew about the importance of setback rules, which are compulsory to follow in house construction. Most of the people $(68 \%)$ in both planned and unplanned areas got information from the KDA officials (Figure 2). Rest of the respondents reported about booklet, neighbor or relatives as their source of information regarding KDA's activities. It may, therefore, be argued that those who had good relation or access to KDA officials, had better knowledge about KDA and planning rules. Survey data shows that planning knowledge is highly correlated with the education status of the respondents. Most of the respondents having better knowledge on planning rules either completed graduate or postgraduate degree (Table 2).

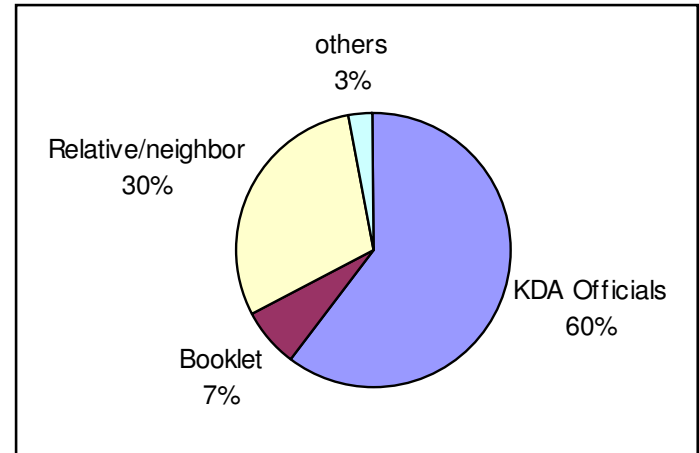

Fig. 2: Source of information to know the services of KDA/planning rules

Table 2: Relation between education level of house owners and their knowledge of planning activities

\begin{tabular}{|l|l|l|l|l|l|}
\hline \multirow{2}{*}{ Knowledge on planning activities } & \multicolumn{5}{|c|}{ No. of responses according to education level } \\
\cline { 2 - 7 } & High School & SSC & HSC & Graduate & Postgraduate \\
\hline Building plan approval & 2 & 10 & 21 & 46 & 30 \\
\hline Overall building construction rules & 1 & 5 & 18 & 42 & 24 \\
\hline Setback rules & 1 & 7 & 10 & 38 & 23 \\
\hline
\end{tabular}

Source: Field survey, 2008

\section{Understanding and practice of Setback Rules by the Citizens}

Applying setback rules in building construction is one of the visible criteria to measure peoples' knowledge, awareness and attitude towards following planning rules. This also shows that how successfully KDA is controlling the planning activities at community level. It was identified that household owners whose land value ranges from BDT 100000-300000 (36\% of the total respondents) were well concerned about the setback rules. Land value higher than BDT 300000 was the second highest group having better planning knowledge. This implies that those owners having lower land value were not aware or they were simply ignorant about the building construction rules prescribed by KDA.

Regarding the practice of KDA guided setback rules, survey data shows that 27 (44\% of the total) buildings in unplanned areas did not follow the setback rules at all or just left space lower than standard limit of $1.5 \mathrm{~m}$ at the front side. Figure 3 shows that a greater number of respondents of 
unplanned areas kept more vacant space (more than $2.5 \mathrm{~m}$ of the standard) in front of their buildings than the planned areas. In planned areas most the households try to ensure optimum use of space as the space is scarce and land value is very high.

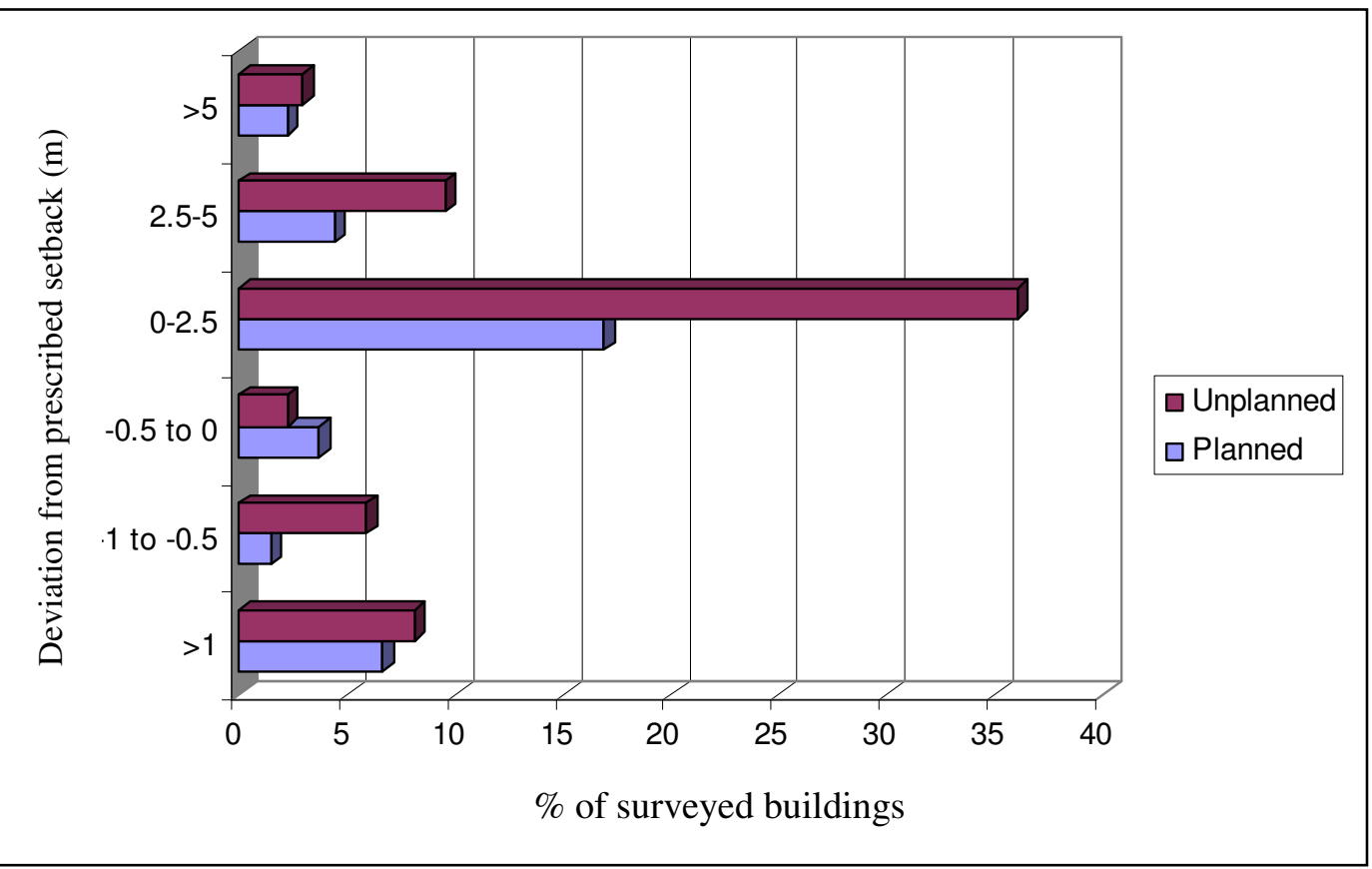

Fig. 3: Deviation of practiced setback from the prescribed rules for the front side of buildings

\section{Citizen's access to Information and Services of KDA}

The respondents reported that bureaucratic complexities is the main hindrance (32\% of the total) in getting permission for building construction from KDA (Table 3). They added that it slowed down the whole process, which was also a result of following manual (paper based) working procedure. Other problems included less cooperative nature of the staff of KDA, corruption and inadequate or incomplete plan submitted by the applicants.

Table 3: Type of difficulties faced by the citizen to get building permission from KDA

\begin{tabular}{|l|c|c|c|}
\hline \multirow{2}{*}{$\begin{array}{l}\text { Type of difficulties encountered by the } \\
\text { applicants }\end{array}$} & \multicolumn{2}{|c|}{ \% of respondents according to their residence } & \multirow{2}{*}{ of total } \\
\cline { 2 - 4 } & Planned area & Unplanned area & \\
\hline Inadequacy of plan provisions & 3.60 & 12.61 & 18 \\
\hline Bureaucratic complexities & 13.51 & 16.22 & 32 \\
\hline Less cooperative staff & 2.70 & 9.01 & 13 \\
\hline Demand for bribe & 9.01 & 14.41 & 16 \\
\hline Others & 4.50 & 14.41 & 21 \\
\hline
\end{tabular}

Source: Authors, 2008 


\section{Peoples' Participation in Preparing Master Plan}

Peoples' participation in preparing Master Plan is the key agenda for any city development authority. In Khulna city, $35 \%$ of the respondents mentioned the name of neighbor/relatives as the source of getting information about Master Plan. Ironically, half of the surveyed citizens did not have any idea of it. It was identified that KDA did not apply any citizen-oriented tool for disseminating information about Master Plan. Finally, sixty responses of the survey came out with the fact that political problem was primarily responsible for unsuccessful implementation of the Master Plan, which was equally voiced by the KDA officials (Table 4).

Table 4: Peoples' opinion regarding the problem of implementation of Master Plan

\begin{tabular}{|c|c|c|c|}
\hline \multirow{2}{*}{ Problem of Implementation } & \multicolumn{2}{|c|}{ No. of responses according to their residence } & \multirow[t]{2}{*}{ Total } \\
\hline & Planned area & Unplanned area & \\
\hline Citizen's demand not incorporated & 13 & 26 & 39 \\
\hline Fund problem & 16 & 30 & 46 \\
\hline Political problem & 28 & 32 & 60 \\
\hline
\end{tabular}

Note: Data was compiled from multiple responses (103 valid cases)

Source: Field survey, 2008

\section{Peoples' Judgment on the Performance of KDA}

It was identified that 68 ( $46 \%$ of the total) respondents lodged complaints to KDA when they faced any problem regarding KDA's jurisdiction in which the rate was high for house owners living in unplanned areas. On the other hand, 30\% of the surveyed citizen remained silent taking no actions to solve their problems. They argued that they had to face various administrative difficulties ( $47 \%$ of the respondents who did not complain to KDA), which restraint them from taking any action (Figure 4).

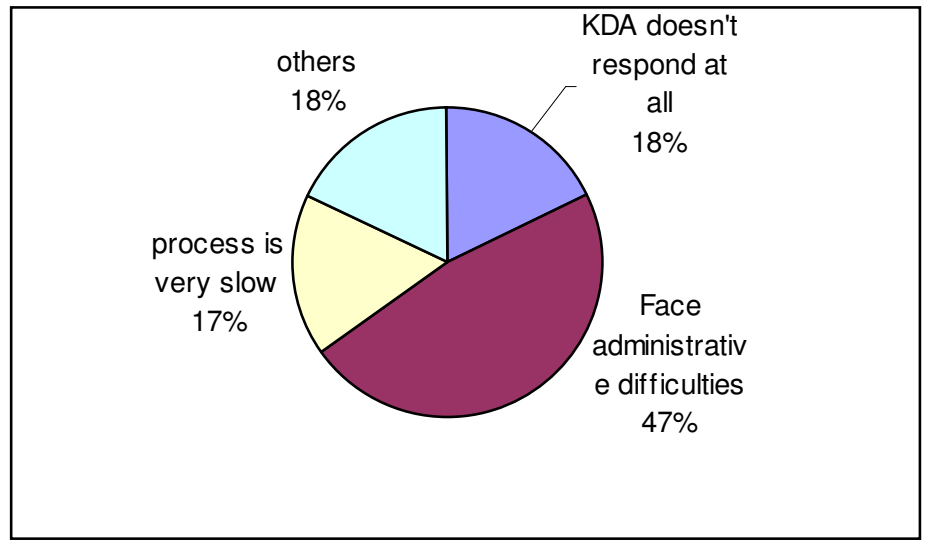

Fig. 4: Factors responsible for not complaining to KDA

Considering access to information and planning activities, $61 \%$ of the surveyed citizens identified limited participation in the jurisdiction of KDA. Their notion fits within the level of P2 and P3 of the Ladder of citizens' participation as indicated in Figure 1 (Arnstein, 1969), which can be defined as information giving and sometimes participation by consultation with citizens (Table 5). 
Table 5: Citizens' opinion regarding the participation in the activities done by KDA

\begin{tabular}{|l|l|l|l|}
\hline \multirow{2}{*}{ Level of public participation } & \multicolumn{2}{|c|}{ \% of respondents according to their residence } & \multirow{2}{*}{$\%$ of total } \\
\cline { 2 - 3 } & \multicolumn{1}{|c|}{ Planned area } & Unplanned area & \multirow{2}{*}{} \\
\hline No participation & 8.72 & 21.48 & 30 \\
\hline Limited level & 18.12 & 42.95 & 61 \\
\hline Highly participated & 2.68 & 2.01 & 5 \\
\hline Community oriented & 2.68 & 1.34 & 4 \\
\hline
\end{tabular}

Source: Field survey, 2008

\section{Creating Space for the Citizen: Tools and Methods}

The study shows that KDA is not taking adequate measures to integrate the citizens in the planning process and as well as to disseminate planning information among the stakeholders. There is scope for introducing new instruments to ensure peoples' participation as recommended by the experts and the community members. The following options can be considered to create more space in the planning process for the citizens (SMCC, 2008) ${ }^{1}$ :

a) Newsletters: A newsletter is an excellent vehicle for informing the public updating the process and describing how people should participate in planning and development. It can present schedules, information about community workshops, key issues, alternative plans, and policy recommendations. The newsletters may emphasize graphics, photos, and illustrations in order to be eye-catching and make the planning concepts easily understood.

b) Community Workshops: Community workshops provide forums for education and brainstorming in interactive settings. Workshops can be structured as events and use innovative participation techniques that engage the interest, maximize opportunities for input, and send a message that the input has been heard and considered in the planning process. Small-group facilitating table-top discussions may be preceded by an open house and introductory presentation. Table-top facilitation can be conducted jointly by consultants (for Master Plan preparation) and KDA staff. A training session on public meeting facilitation techniques can be conducted by the consultants focusing on the challenges of facing public participation.

c) Traveling Road Show: KDA staff and the consulting firms can work together to prepare a "traveling road show" that enables staff or "community ambassadors" to serve as facilitators of community involvement efforts. A kit can be developed containing "traveling road show" materials, which will include large-scale graphics, handouts and techniques for addressing the media.

d) Community Briefings: An important step in the public participation process is to establish contact with key constituencies in Bangladesh: community groups, building industry groups, environmental organizations, the Chamber of Commerce, and other relevant parties. Ongoing neighborhood and business groups provide excellent leveraging opportunities for the planning team to keep community members informed and gain feedback. Consultant and/or KDA staff may track these meetings, and make short presentations or announcement periodically, using road shows where appropriate.

e) Focus Group Discussions: Focus groups enable qualitative discussions with a small number of randomly selected people, brought together to discuss potential choices, especially in designing and evaluating alternatives and a preferred plan. Unlike the one-way flow of information in a oneon-one interview, focus groups generate data through the give-and-take of group discussion.

${ }^{1}$ www.smgov.net/cityclerk/council/agendas/2004/20041026/s2004102608-A-1.pdf (accessed on 28 June, 2008) 
Listening as people share and compare their different points of view provides a wealth of information - not just about what they think, but why they think the way they do.

f) Children and Youth Programs: One of the most effective public outreach techniques is the involvement of local schools. This may involve activities in which children either participate directly or serve as the conduit of information to their parents. The former can include input regarding the students' perception of community issues and their vision about the future. Drawing pictures and making collages of their favorite and least favorite places, making plans for neighborhoods and districts; writing essays about community issues and their visions for the future of the city and/or responding to questionnaires, the young children can communicate to the Development Authority about the type of city they practically would like to live.

\section{Conclusion}

The findings of the research indicate that there is a little scope for public participation in urban planning and development of Bangladesh. There are many statutory laws and by-laws prevailing in Bangladesh, but due to various barriers, most of the laws remain dormant. Public participation has not been encouraged by planning and environmental laws and policies. Lack of time-worthy laws, lack of awareness of the citizens, requirement of higher costs and resources, and institutional constraints are the main reasons hindering improvement in this sector. The ultimate purpose of citizens' involvement is to integrate their opinion into collective actions and decisions. It is important that participation must start at the beginning of the planning process, so people can notify their actual problems to the planners and let them get the most appropriate alternatives for sustainable urban development in Bangladesh.

\section{References}

Arnstein, S. R. 1969. A Ladder of Citizen Participation, Journal of American Institute of Planners (JAIP), vol. 35(4), pp. 216-224.

Enyedi, G. 2004. Public Participation in Socially Sustainable Urban Development. Budapest: UNESCO/MOST Program and Center for Regional Studies (Hungarian Academy of Sciences).

Innes, J. E. and Booher, D. E. 2000. Public Participation in Planning: New Strategies for the 21st Century. The Annual Conference of the Association of Collegiate Schools of Planning, California, Institute of Urban \& Regional Development - University of California, Berkeley.

Islam, N., Teerlink, H., Nazem, N. I., \& Alam, M. S. 2001. Local Partnership Approach for Urban Development in Bangladesh: A Comparative Study of Four Participatory Urban Development Projects. Dhaka: Center for Urban Studies (CUS).

Lane, M. B. 2005. Public Participation in Planning: an intellectual history. Australian Geographer, Vol. 36(3), pp. 283-299.

Lehtonen, S. Public Participation in Urban Planning and Strategies: Lessons from medium sized cities in the Baltic Sea Region. Copenhegen, Danish Centre for Forest, Landscape and Planning, http://www.mecibs.dk/brochures/07Publicpart.pdf, retrieved on 5 March, 2007).

Maier, K. 2001. Citizen Participation in Planning: Climbing a Ladder? European Planning Studies, vol. 9(6), pp. 707-719.

Mikkelsen, B. 2005. Methods for Development Work and Research - A New Guide for Practitioners. London: Sage Publication.

Mitchell, B. 1997. Resource and Environmental Management, London: Longman.

Santa Monica City Council (SMCC), 2008. Santa Monica: Land Use Element and Zoning Ordinance Update, www.smgov.net/cityclerk/council/agendas/2004/20041026/s2004102608-A-1.pdf, retrieved on 28 June, 2008) 